International Conference on Heritage in Asia: Converging Forces and Conflicting Values

8-10 January 2009, organized by the Asia Research Institute, National University of Singapore Seminar Room A, B, C \& D, Block AS7, Shaw Foundation Building, Level 1

\title{
Western Conservation Theory and the Asian Context: The Different Roots of Conservation
}

\author{
Timoticin Kwanda \\ Petra Christian University, Surabaya-Indonesia
}

kwanda_t@nus.edu.sg

\begin{abstract}
In the mid twentieth century in the Western world, classical conservation theories emerged that seek to preserve and recover the integrity and authenticity of an object. In conservation practice throughout Europe and the international sphere, this materialistic notion of conservation is found in various international charters, such as the Athens Charter, and the Venice Charter. This notion of Western conservation has been disseminated throughout the world by UNESCO and its advisory body, ICOMOS. For decades, this tangible notion of conservation have been imposed in conservation practice in Asian countries, such as the first wave of conservation happened after the World War II when the new emerging nations were celebrating their nationalism through the state's construction of colonial heritage. In the 1990s, as part of the globalised economic development, the second wave of tangible notion of conservation took place through the state's construction of cultural heritage as resources for tourism industry. After the 1990s, the notion of cultural significance, meaning or value has shifted the focus of conservation from the object to the subject: the people that associated with a place. In similar focus on the subject, in 1994, Nara Document on Authenticity was adopted to challenge the Western physical notion of heritage with the intangible notion of heritage. In response to this notion, in recent years a number of Asian countries have their own charters to underpin approaches in conserving of cultural heritage. Unfortunately, this Charters still strongly hold the doctrine of tangible notion as taught in the Venice Charter. In contemporary conservation practice in Asia, the third wave of conservation in Asia was the challenge of the experts against the domination of the state on the production of cultural heritage that has also contributed to this shift from the object to the subject. This notion was followed in the 2000s by conservation practice throughout Asia that focus on the inclusive approach and intangible heritage as recorded in the 2000-2004 UNESCO-Asia Pacific Heritage Award. This paper tries to argue that in the parallel course of conservation history the conservation theory in Asia should be rewritten rooted in the different and long traditions of Asia society that emphasize the spiritual meanings of the people reflecting through the object and the tradition of fabric renewal of the perishable structure as opposed to the notion of material authenticity that keep the principle of minimum intervention and reversibility as known today in conservation theory and practices.
\end{abstract}

Keywords: Charters; Classic and Contemporary Conservation Theory; Intangible Heritage. 


\section{ABOUT THE SPEAKER}

Timoticin Kwanda is a lecturer at the Department of Architecture, Petra Christian University, Surabaya-Indonesia, in which he was the Head of the Department of Architecture from 2001 to 2006. Now, he is a PhD candidate in the Department of Architecture, National University of Singapore. He completed his Bachelor of Science and Master of Regional Planning in Urban and Regional Planning, Cornell University, USA in 1986 and 1988 respectively. He studied architecture in the Department of Architecture, Petra Christian University, from 1978 to 1983 . He received a research grant from The Toyota Foundation Program for Young Researchers in 1989 to conduct a research on the Inventory of historical buildings in Surabaya. His main research interest is conservation of cultural heritage in Indonesia with the recent papers include 'The Living Heritage: Authenticity and Sustainable Conservation of Cultural Heritage in Asia' in World Heritage and Sustainable Development, vol. 1, eds. R, Amoeda, et al. 2008, Green Lines Institute for Sustainable Development, Barcelos, Portugal; 'The Interpretation of Cultural Heritage: the Living Authenticity and the Sense of Place', ICOMOS Thailand International Symposium, 2007; 'Potential and problems of Surabaya upper city as a historical conservation area' in Kota lama kota baru: sejarah kota-kota di Indonesia, eds. Freek Colombijn et al, 2005; 'The inventory of Darmo residential area in Surabaya', mAAN $3^{\text {rd }}$ International Conference, 2003; 'The Inventory of Colonial Architecture in Surabaya: Learning from the Past', $m A A N 2^{\text {nd }}$ International Conference, 2002. He is a proffesional member of the Indonesian Planner Association, and also a member of the Indonesia Network for Heritage Conservation, and the Indonesia Heritage Trust.

\section{INTRODUCTION}

At present in conservation, two different academic streams existed that totally conflict on the notion of the primacy of the heritage object, the first one considering that the object has a value existing independently of people that should not be threatened to any change. ${ }^{1}$ The second one, the people-centred approach views that heritage is inevitably rooted more about people of the present as creators of heritage, who attribute meaning, value, and functions and select what is to become heritage from the past. ${ }^{2}$ These two notions of heritage approach are also termed as classical conservation theory developed since the eighteen century and contemporary conservation theory developed since the 1980 s. $^{3}$ The notion of theory is related to conservation ethics or convention as commonly understood in many conservation charters throughout Europe and the international sphere. In Asian countries, conservation is a new concept, notably in recent years a number of Asian country has charters to underpin approaches in conserving cultural heritage, such as the Chinese Principle (2000), the Hoi An Protocols (2001), and the INTACH Charter (2004). This paper explores the challenge and change of conservation theory as described in some recognised international or national charters and documents on conservation of cultural heritage. It discusses the importance of material objectivity which origins from the European context, and examines the challenge of the tangible

\footnotetext{
1 Conservation means 'all the process of looking after a place so as to retain its cultural significance' (Burra Charter 1999), similarly conservation is defined as "the action taken to prevent decay and manage change dynamically", and all of these acts are to "prolong the life of our cultural and natural heritage ...", see B.M. Feilden (2003), Conservation of Historic Buildings, Architectural Press, Oxford, p. 10.

2 T. Loulanski (2006), 'Revising the concept for cultural heritage: the argument for a functional approach, International Journal of Cultural Property vol. 13, p. 215.

3 S.M. Vinas (2005), Contemporary Theory of Conservation, Elsevier-Butter Worth-Heinemann, Amsterdam, pp. 6-7.
} 
quality of the objects, and consequently the intangible dimension is added into the conservation theory in Asian experience. This paper also describes the shifting of conservation theory from the classical theory to the contemporary theory which centre on the subject. Finally, it tries to argue that conservation theory in Asia should be rewritten rooted in the different and long traditions of Asia society that emphasize the spiritual meanings of the people reflecting through the object and the tradition of fabric renewal for the perishable structure as the majority of the heritage. ${ }^{4}$

\section{CLASSICAL CONSERVATION THEORY}

Classical conservation theory emerged in the Western world that seek to preserve and restore the aesthetic integrity of an object based upon soft science-the aesthetics theory, and the hard material science - the scientific theory. ${ }^{5}$ Since the nineteenth century, the desire to preserve as much of the original fabric as possible has been key to conservation practice, which has viewed the original material as the ultimate testimony to the history and origin of the building, and thus to its authenticity as a cultural and historical artefact. This practice of the concept has served as one of the major philosophical underpinnings of conservation for the last hundred years and continues to be the focus of discussion in conservation discourse, from the onset of the restoration debate in the nineteenth-century England, the Athens Charter (1931), and the Venice Charter (1964) in Europe, to the international sphere of UNESCO World Heritage Convention (1977), and the ICOMOS Charter for the Conservation of Historic Towns and Urban Areas (1987).

\section{Preservation and the Romantic Movement}

In the end of eighteenth century Europe, art and thus its object gained a special status within society, and fine arts academics became common around Europe. In the nineteenth century, this trend was especially intense in England, where the Arts and Crafts movement had a strong cultural impact among artist, art lovers and the public. One of the prominent English art writer and draughtsman was John Ruskin who had a strong influence over public opinion with his well-known book The Seven Lamps of Architecture (1849) that strongly appreciates the virtues and values of ancient building, and a love for the past that disregard for the restoring of the original remnants from the past. One of the proponents of restoration movement was the French architect, Violletle-Duc who restored Notre Dame of Paris, trying to fill-in-the-blanks of damaged buildings restoring to the original state when it was conceived as original idea of the creator. Thus, for Ruskin restoration was 'a lie', and as the voice of anti-restoration movement, he establishes the important of material authenticity and minimal intervention in the existing historic fabric as still practiced today.

In response to this growing impact of restoration, in 1877, the Society for the Preservation of Ancient Buildings (SPAB) published a manifesto written by William Morris that addressed the respect of original fabric, appreciation of original craftsmanship, ruins, picturesque decay, the look and feeling of weathered materials (patina) as integral to authenticity of the experience and the integrity of historic fabric. Thus, the emphasis on the authenticity of materials must be seen in context and its origins in the late nineteenth-century English Art and Crafts movement, a romantic vision of decaying ruins

\footnotetext{
4 The term cultural heritage is used to mean all heritages that is intentionally constructed and biased toward a particular group or issue see D. Lowenthal (1998), The Heritage Crusade And the Spoils of History, Cambridge University Press, Cambridge; and the concern of the paper is the cultural heritage at large and the built heritage in particular.

5 S.M. Vinas, op.cit. pp. 6-7.
} 
that led to reverence for authentic historic object and its craftsmanship (Prudon 2008). Ruskin and Viollet-le-Duc are considered to be the first true conservation theorists, and their position can hardly be reconciled. To alleviate this situation, several institutions made attempt at normalization through the promulgation of charters, normative documents of an agreement between professional conservators and specialists (scientists). Nonetheless, Ruskin's perspective and the SPAB Manifesto is the earliest and important notion in establishing principles for preservation and restoration that reflected in the following documents such as the Athens Charter and the Venice Charter.

\section{Reconstruction after the World War I and II}

During the World War I wide-scale destruction happened in Europe, as a result repair works of monument after the war were allowed through the available resources and techniques. This development reflects in the Athens Charter issued at the First International Congress of Architects and Technicians of Historic Monuments in 1931 that allows for repair of monuments unlike the earlier SPAB Manifesto. ${ }^{6}$ For repair works, new materials and techniques such as reinforced concrete was introduced to recover the original building. Partial reconstruction of the missing section (anastylosis) was conducted, and kept clearly recognizable as a new to create a more complete experience of the building as it was originally constructed. The Charter was the first document to set out the scientific principles for the preservation and restoration of historic monuments at the international level, however states no words on authenticity, yet the closest meaning of authenticity is stated '... steps should be taken to reinstate any original fragments that may be recovered' (Article VII).

After the World War II, in 1964 the International Charter for the Conservation and Restoration of Monuments and Sites, the so-called Venice Charter, was adopted at the similar Second International Congress in Venice which mostly attended by the European delegates. ${ }^{7}$ Like the Athens Charter, this Charter was developed after the World War II when much of Europe was being constructed therefore its conservation principles reflected much of this post-war conservation and reconstruction of decayed or damaged architecture by acts of war. ${ }^{8}$ The document is a revision of the Athens Charter that emphasis on scientific methodologies, the importance of the aesthetic and historical significance of both the original fabric, the first document to set out the concept of authenticity as stated in the preamble '... to hand them on in the full richness of their authenticity.' Hence, the respect for original materials remained paramount to the means for achieving authenticity as stated 'Its aim is to preserve and reveal the aesthetic and historic value of the monument and is based on respect for original material and authentic documents' (Article 9).

\section{Homogenization of Conservation Theory to the World}

In this Second conference, UNESCO also put forward for the creation of the International Council on Monuments and Sites (ICOMOS). Founded in 1965, ICOMOS is dedicated to bring together conservation specialists and promoting the application of theory, methodology, and scientific techniques to the conservation of the architectural and archaeological heritage 'based on the principles enshrined in the 1964 Venice Charter' as

6 T. H.M. Prudon (2008), Preservation of Modern Architecture, John Wiley \& Sons, Hoboken, pp. 54-56.

7 This document was drafted by one representative of UNESCO, two delegates of ICCROM, and mostly by 17 persons from Europe such as Austria, Belgium, Czechoslovakia, Denmark, France, Greece, Italy, Netherlands, Portugal, Poland, Spain, Vatican, Yugoslavia; two persons from South America: Mexico and Peru; only one from Africa: Tunisia, and none from Asia (see Fielden 2003: p. 362).

8 W. Deslagen (1994), Architectural Restoration in Western Europe: Controversy And Continuity, Architectura \& Natura Press, Amsterdam, p. 237. 
the principal doctrinal document (see statements in About ICOMOS) ${ }^{9}$. The Charter is exported as reflected in the 1976 US Secretary of Interior's Standards which guides conservation in the United States, and also became the reference point for many of the later charters at the international and national level around the world. In other words, conservation theory of the Venice charter which originated from the European local context and drafted by mostly Europeans is applied went beyond national borders for homogenization of Western influence through ICOMOS, and this is referred as the Authorised Heritage Discourse (AHD) which 'has achieved hegemony realised linguistically and flourish to promote a consensus approach to conservation of heritage'. ${ }^{10}$

In the international level, the homogenization of conservation principles were introduced by UNESCO and ICOMOS through the 1972 UNESCO World Heritage Convention in which in its preamble prescribed the basic criterion of 'outstanding universal value' for cultural heritage to be inscribed on the World Heritage List. This notion of 'outstanding universal value' is seen as a paradoxical situation as 'universality' appeared to be incompatible with the essential diversity of human culture. ${ }^{11}$ The contradiction also reflected in the composition of the inclusion of world cultural property. In the 2000 World Heritage List, 630 sites and monuments shows that 55 per cent of them are situated in European countries, this figure rises to 60 per cent of those in Canada and the USA. The Asian inscription in China and India are account for only 14 percent, and a mere 1 per cent in Asia Pacific. ${ }^{12}$ Indeed, this imbalances was acknowledged and highlighted in the report on the Global Strategy and Thematic Studies as noted that 'Europe was overrepresented in relation to the rest of the world'. ${ }^{13}$ The World Heritage list, however, is indicative of the Eurocentric perception of cultural heritage that emphasis on the notion of authenticity relating to monumental culture as stated that 'the problem is one of overrepresentation of particular types of monument proposed by a small group of member countries'. ${ }^{14}$ This notion of material authenticity also reflects in other international documents, in the urban scale for example, the 1987 ICOMOS Charter for the Conservation of Historic Towns and Urban Areas (the Washington Charter) states that "Any threat to these qualities would compromise the authenticity of the historic town or urban area" as refer to historic character such as urban patterns, the formal appearance of the buildings (scale, size, style, materials, colour and decoration), the surrounding setting, and the functions of the area (Article 2).

In short, through the official instruments: charters, recommendations, well-endowed institutions, and member states, these 'authorized' international organizations have advantages and power to establish what counts as heritage, what its value is, where resources should go, and what cultural heritage matter in the context of selected times and places for the world. This globalising of conservation practice of these international organisations is a powerful one, as they lay 'down international standard for professional

9 ICOMOS carries substantive authority in making pronouncements about the nature and meaning of heritage, and provides advice to national governments and international organization about the philosophy, terminology and methodology for conservation practices.

${ }^{10}$ E. Waterton, L. Smith \& G. Campbell (2006), 'The utility of Discourse Analysis to heritage studies: the Burra Charter and social inclusion', International Journal of Heritage Studies, vol. 12, no. 4, pp. 339-355.

${ }^{11}$ H. Cleere (2001), 'The uneasy bedfellows: universality and cultural heritage' in Destruction And Conservation Of Cultural Property, eds. Layton, R., Stone, P.G. \& Thomas, J., Routledge, London, p. 24.

12 H. Cleere, op.cit., p. 25; and Fu C.C. (2005), 'Cultural sensitivity towards intangible values in monuments and sites-a comparison between Eastern Asian and Western countries', ICOMOS 15th the Scientific Symposium, Xi'an.

${ }^{13}$ ICOMOS 2005, The World Heritage List: Filling The Gaps - An Action Plan For The Future, ICOMOS, Paris.

${ }^{14} \mathrm{~K}$. Emerick (2001), 'Use, vale and significance in heritage management' in Destruction And Conservation Of Cultural Property, eds. R. Layton, R., Stone, P.G. \& Thomas, J., Routledge, London, p. 283. 
International Conference on Heritage in Asia: Converging Forces and Conflicting Values

practice in the cultural heritage field', and 'imposing a common stamp on culture across the world and their policies crating a logic of global cultural uniformity to impose standards of "good behaviour" onto Member States and other states' (Logan cited in Taylor 2004).

\section{CLASSICAL CONSERVATION PRACTICE IN ASIA}

The urban heritage in Asia context, especially Southeast Asia generally has been greatly shaped by both colonial and post-colonial changes. The colonial ports and capital cities were developed to serve the purpose of colonial power to meet the administrative and trading needs where the major links between the centre and hinterland economies, flowing between them by articulating the flow of capital, labours and commodities and culture. ${ }^{15}$ Consequently, colonialism had a major impact on urban form and heritage, networks and functions, individual building design, street layouts, the segregation of ethnic groups and the development of urban utilities all reflected to a greater or lesser extend the tenets of colonial design and practice, especially in the colonial district. ${ }^{16}$ In the other parts, the presence of distinct areas such the Chinese quarter that is lively, visually "chaotic" consists of densely packed rows of shophouses selling a variety of goods and providing numerous services; and the local quarters with the irregular residential pattern and traditional wooden houses still visible in parts of the city. With the process of decolonisation from the end of the Second World War, the economic processes, the built form and the ethnic segregation of the cities have remained unchanged. ${ }^{17}$ Unfortunately, the homogenized-authorized conservation principles were applied to these distinct quarters in Asia in the following discussion.

\section{The First Wave of Conservation: Celebrating the Nation}

The first wave of conservation was developed limited by the ruling class and their apparatus who gains the knowledge from the collaboration with the former colonists and the 'authorized' international organization in the previous conservation works especially ancient monuments such as Angkor Wat in Cambodia, and Borobudur in Indonesia. ${ }^{18}$ The notion that emphasises the importance of built fabric authenticity has also been imposed in the mind of the states and the technocrats in Asia through many conservation guidelines. For example, the legal protection to a building as heritage in Hong Kong is graded based upon 'monumental quality' as outlined in the Antiquities and Monuments Ordinance enacted in 1976). ${ }^{19}$ In Indonesia the 1992 Cultural Heritage Ordinance is evolved from and similar to the 1931 Dutch Monumenten Odonantie Stbd No. 283, and in Singapore, the URA conservation principles are drawn from international sources such as the Venice Charter, the US Secretary of the Interior's Standards for Rehabilitating Historic Buildings, and the Burra Charter (1988 version). ${ }^{20}$

\footnotetext{
${ }^{15}$ A. Reid (1993), Southeast Asia in the Age of Commerce 1450-1680, vols 2. Yale University Press, New Haven, pp. 77-90.

16 J. Widodo (2004), The Boat and the City: Chinese Diaspora and the Architecture of Southeast, Marshall Cavendish Academic, Singapore, pp. 90-93.

17 M.C. Cleary (1997), 'Colonial and post-colonial urbanism in north-west Borneo, in Contested Urban Heritage: Voices From The Periphery, B. Shaw \& R. Jones, Ashgate, Singapore, p.15.

${ }^{18}$ For example Borobudur was restored with UNESCO's help in the 1970s.

19 Chu C. (2007), 'Heritage of disappearance? Shekkipmei and collective memory(s) in post-handover Hongkong', Traditional Dwellings and Settlements Review, vol. XIII, no. 2, pp. 4355.

20 N. Supardi (2003), Pedoman Rehabilitasi Bangunan Bersejarah, Jakarta, p. xiv; and Urban Redevelopment Authority (1993), Objectives, Principles and Standards for Preservation and Conservation, Preservation of
} Monuments Board, Singapore, p 12. 
This imposed knowledge was then moved to former colonial districts as the ruling power of heritage is particularly strong in urban areas, as it is here that the economic interests are often highest, in term of land and commercial values, and political symbolism is at its most potent in regional, state and national capitals. ${ }^{21}$ In these post-colonial capitals, colonial buildings and local neighbourhood were conserved as a continuity of colonial state. After the World War II, Anderson (1991) stated that the 'last wave of nationalism' in Asia was the result of the transformation of the colonial-state to the national state, and to preserve this 'imaginary community', illumination and glorification of certain aspects of history are needed or history selectively commodified for political ends. ${ }^{22}$ For example, in the old district of Jakarta, despite the existence of distinctly Chinese and the other districts, only the Fatahillah Square, named after the $16^{\text {th }}$-century Muslim conqueror of the formerly Hindu state, was selected in 1973 as the first urban conservation work by the authority. ${ }^{23}$ Colonial buildings were conserved for a repository of Indonesian cultural artefacts, such as the former Town Hall now house as the museum displaying relics of Dutch colonial life juxtaposed with Indonesian and the local Betawi exhibits, the old VOC warehouse become the national maritime museum, and a former church functions as the wayang kulit museum. This intention also reflects in the official tourist guides whereas these colonial buildings are identified by their contents as the museums rather than by their origin. ${ }^{24}$ In Surabaya, most of the colonial buildings were listed for ideological ends to preserve the memory of heroic battle of the arek or the people of Surabaya against the Dutch and the British army in 1945.

\section{The Second Wave of Conservation: Urban Development and Tourism Industry}

In the 1990s, the second wave of conservation, the urge of popular interest in conservation was popularized by the states through publications of aestheticized and romanticized heritage from popular magazines, commercial adverts, to tourist guidebooks, maps, brochures, and websites provided by authoritative agencies for tourism industry. The past was wrapped up in a pleasant form for commercial consumption to embrace economic globalization especially tourism industry. Some examples such as the conservation of Intramuros of Manila for tourism, the $16^{\text {th }}$ century Spanish fortified town, suffered extensive American bombing during World War II, and degenerated into a shanty town. ${ }^{25}$ Shanghai government has created the historical protection zones such as the Bund along the Huangpu riverfront and the Western concessions district after the period of massive urban development boom of the $1990 \mathrm{s.}^{26}$ The Fatahillah Square in Jakarta was conserved for both tourism and new urban development through adaptive used of the colonial buildings and reinvented the colonial $19^{\text {th }}$ century Batavia. ${ }^{27}$

${ }^{21}$ B.J. Shaw \& R. Jones eds. (1997), Contested Urban Heritage: Voices From The Periphery, Ashgate, Singapore, $\mathrm{p} 2$.

22 B.R.O'G Anderson (1991), Imagined Communities: Reflections On The Origin And Spread of Nationalism, Verso, London. ; and E. Hobsbawm \& T. Ranger eds. (1989), The Invention of Tradition, Cambridge University Press, Cambridge, pp. 1-14.

23 J.L. Cobban (1985), 'The ephemeral historic district in Jakarta', Geographical Review, vol.75, no.3, pp. 300318.

${ }^{24}$ R. Jones \& B.J. Shaw (2006), 'Palimpsets of progress: Erasing the past and rewriting the future in developing societies - case studies of Singapore and Jakarta', International Journal of Heritage Studies vol. 12, no. 2, pp. 122-138.

${ }^{25}$ F.T. Maclaren \& A. Villalon (2002), 'Manila's Intramuros: storming the walls' in The Disappearing 'Asian' City: Protecting Asia's Urban Heritage In Globalizing World, ed. W.S. Logan, Oxford University Press, New York.

26 S. Balderstone, Qian F. \& Zhang B. (2002), 'Shanghai reincarnated' in The Disappearing 'Asian' City: Protecting Asia's Urban Heritage In Globalizing World, ed. W.S. Logan, Oxford University Press, New York.

27 J.L. Cobban, op.cit., pp. 300-318. 
The Chinatown in Singapore grew and became the centre of the Chinese coolie trade, crowded with hawkers selling a variety of goods, noise and congestion made up the daily life. This typical scene continued until the 1990s when conservation was enforced by the Urban Redevelopment Authority to increase the decline of tourist arrivals, then hawkers were relocated and many old shop-houses were adapted for new uses such as office, boutiques or demolished for new flats. As a result, the place is criticized for the lack of spontaneity and authenticity in representing the former vibrancy of Chinatown spirit due to the shopping and street activities. ${ }^{28}$ Similarly, this state-led conservation for tourism has been also applied in the reconstruction of the Kampung Gelam and Geylang Serai. ${ }^{29}$ In 1990s, China has also experienced rapid urban development that destroyed many historic districts, and to conserve these districts the municipality welcomed investment with immediate revenue, thus tourism was adopted as a strategy for conservation. This state's policy however has threatened the quality of historic districts that ignores local community services, excludes suitable modern uses of historic buildings, and even the construction of fake historic scene, such as the Jinli Old Street in Fujian, the Wuyi Mountain Old Street in Hubei, and the Fuyang Paper Making Old Street in Zhejiang Province. ${ }^{30}$

It is agreed that it is usual for a dominant group to use its power to push its own heritage to the fore, minimizing or even denying the significance of subordinate groups. ${ }^{31}$ As in these two waves of conservation practices in Asia, the asymmetry axis of power has caused the ordinary people were excluded in conservation. This exclusion due to the main concern of conservation was the intactness of the physical environment as it taught by the Eurocentric classical conservation dogma, although the objects were often conserved inaccurately without meticulous research.

\section{CONTEMPORARY CONSERVATION THEORY}

Twentieth-century conservation theory and practices developed from a nineteenthcentury base which initially focusing largely on singular, monumental artistic expression in art and architectures, and today they encompass groups of buildings and sites, historic gardens and landscape, historic towns, vernacular architecture, intangible cultural properties, and cultural landscape. Along with the widening scope of heritage, contemporary theory primary interest is no longer on the objects, but rather on the subjects based on the basic question that why, for whom, the conservation is done. The answers to these questions are closely to the reason that objects are conserved because it has meaning for some or a certain group of people in which these meanings are neither fixed, nor are they universal as the same object can have a strong significance for some people, while being irrelevant to other; the responsibility for conservation of an object fall on the affected people, thus it is their duty to conserve, and it is for them that conservation is performed; conservation objects is not an experts-only zone that decisions are beyond the reach of most people. ${ }^{32}$ Three characteristics have emerged from the contemporary theory as discussed in the following.

\footnotetext{
28 J. Henderson (2000) 'Attracting tourists to Singapore's Chinatown: a case study in conservation and promotion', Tourism Management vol. 21, pp. 525-534.

${ }^{29}$ R. Powell (1997), 'Erasing memory, inventing tradition, rewriting history: planning as a tool of ideology' in Contested Urban Heritage: Voices From The Periphery, B. Shaw \& R. Jones, Ashgate, Singapore.

${ }^{30}$ Zhu Q. (2007), 'Historic district conservation in China: assessment and prospects', TDSR vol. XIX, no. 1 , pp. 59-76.

31 P.P.A. Funari (2001), 'Destruction and conservation of cultural property in Brazil: academic and practical challenges' in Destruction And Conservation Of Cultural Property, eds. Layton, R., Stone, P.G. \& Thomas, J., Routledge, London.

32 S. M. Vinas, op.cit., p. 177.
} 


\section{The Idea of Significance}

The idea of significance was first appeared as an archaeology term in the 1970s, and in the late 1980 s and early $1990 \mathrm{~s}$, significance begins to appear more frequently in the British and American conservation vocabulary. ${ }^{33}$ In the 1980 s, this idea emerged due to some thoughts that not everything from the past could and should be saved, that heritage had to pay its own way, the dwindling financial resource coupled with a more realistic estimation of the actual cost of conservation, and that historic buildings or sites had a significance because they had been developed, modified, used for many years. Therefore it is unrealistic to take a purist line to seek the historic and aesthetic truth of the object in conservation. In 1990s, the idea of significance has become commonplace stemming from its use in the Burra Charter, where it is presented as 'cultural significance'. ${ }^{34}$ 'Cultural significance' is a concept which helps in estimating the value of places and encompasses attributes such as 'historic', 'social' or 'scientific'. Once significance is known it is then possible to construct policies or conservation plans as a tool to manage change which will protect that significance, and facilitate development.

The idea of significance which embraces value becomes use related, and in fact, the notions of value, meaning, and function are very similar, mostly a matter of terms whereas an object with symbolic value or meaning fulfils a symbolic function; an object with economic value fulfils economic function. ${ }^{35}$ Another contemporary theory related to value is the value-led conservation developed by several authors associated with the Getty Conservation Institute that closely related to functional views of conservation: a set of values placed upon an object given by people. The main notion of the value-led conservation is that conservation decision making should be based on the analysis of the values an object possesses for different people in order to reach an equilibrium among all parties involved new groups have become involved in the creation and care of heritage such as professionals from such fields as tourism and economics, and communities arrive with their own criteria and opinions. ${ }^{36}$

\section{Inclusive Approach}

The Burra Charter also adopted an inclusive approach that focus on material artefacts have shifted to the subject that attempt to prioritise public interest '. . . conservation, interpretation and management of a place should provide for the participation of people for whom the place has special associations and meanings, ....' (Article 5.1). However, while the Charter has attempted to incorporate the subject such community inclusion, participation and consultation, this attempt remains unsuccessful due to the uncritical acceptance of a dominant or authorised approach to heritage' in which the experts as activated subjects, who make things happen, and non-experts act only as audience status. ${ }^{37}$ Another contradictory issue is the notion of heritage, while written for an Australian context, the Charter has become an integral part of the Eurocentric common sense as it took and accepted the underlying philosophy of the Venice Charter. Throughout the Charter the emphasis is strongly towards 'maintaining the fabric of a

\footnotetext{
${ }^{33}$ K. Emerick, op.cit., p. 279-280.

34 In 1999, the Burra Charter was revised to include not only fabric with its aesthetic, historic, and scientific values but also use, associations and meanings such as spiritual and the indigenous value. This international widely known document, originally drafted in 1979, in 1999 underwent its third and most substantial revision following minor revisions in 1981 and 1988.

35 S. M. Vinas, op.cit., p. 180-181; and K. Emerick, op.cit., p. 281.

${ }^{36}$ R. Avrami, R. Mason \& M. De La Torre, eds. (2000), Values and Heritage Conservation, Getty Conservation Institute, Los Angeles.

${ }^{37}$ E. Waterton, L. Smith \& G. Campbell, op.cit., pp. 339-355.
} 
place in its existing state' (Article 1.6), hence, authenticity is perceived to be residing in the frozen fabric (existing state) that separated from the present time that link 'intertextually incorporated' with the Venice Charter and authorised heritage discourse. Thus, this notion of heritage has antecedents back to European antiquarian assumptions that artefacts embodied, or even contained a fixed meaning. ${ }^{38}$

\section{Intangible Heritage}

During the ICOMOS general assembly in 1990, it was decided to evaluate the Eurocentric principles of the Venice Charter. ${ }^{39}$ Few years later, in 1994 a conference was held in Nara, Japan aimed to challenge conventional thinking of the notion of material authenticity, organized by the World Heritage Convention in co-operation with UNESCO, ICCROM and ICOMOS. In the conference, the experts compromised that the concept and application of authenticity of cultural heritage must consider and judge within the cultural contexts. As the result, the Nara Document on Authenticity was adopted that proposes assessments of authenticity should encompass matters relating to 'form and design, materials and substance, use and functions, traditions and techniques, location and setting, and spirit and feeling, and other internal and external factors' (Article 13). It acknowledges the plurality approach to the issue of authenticity that does not reside primarily in Western notion of intact fabric, and acknowledges local traditions and intangible values. This represents a pace of change from the European-oriented definition of materially original to embrace non-European cultural traditions or the intangible cultural heritage..$^{40}$

Following the spirit of the Nara Document, in 2000 the Principle for the Conservation of Heritage Sites in China (the Chinese Principles) was developed by ICOMOS China in cooperation with the Getty Conservation Institute and the Australia Heritage Commission. The Principles addresses intangible cultural context aspects of historical such as significant events, customs, traditions or social practices, and artistic values derives from its historic authenticity, and adopts traditional intervention practice such as annual or seasonal repair that involves only minor repair and maintenance. ${ }^{41}$ However, a strong Western notion of conservation is still present in the Principles as the Venice Charter is cited in the Preface as 'the most representative document of international principles in this field,' and 'The aim of conservation is to preserve the authenticity of all the elements of the entire heritage site . . . .' (Article 2) Thus, the retention or original fabric even for timber buildings in China has been included in the Chinese Principles as encouraged in international charters born in the Western context of dominated masonry structures. ${ }^{42}$

In other parts of Asia, the response to the Nara Document was the conservation experts meeting promulgated by UNESCO held in Hoi An, Viet Nam in March 2001 that adopted the Hoi An Protocols for Best Conservation Practice in Asia. It rectified the whole nature of the Nara Document, as relevant to the conservation of Asian heritage, and the notion of authenticity is primarily similar to the Nara Document (paragraph C), yet it reaffirmed

\footnotetext{
${ }^{38}$ Ibid. p. 350.

${ }^{39}$ W. Deslagen, op.cit, p. 237.

40 The authenticity as defined by non-Eurocentric cultures gained prominence during the last two decades, and consequently, the four elements of test of authenticity in the earlier version of the UNESCO World Heritage Operational Guidelines have been expanded into the elements that almost similar in the Nara Document in the latest World Heritage Operational Guidelines (2005).

${ }^{41}$ D. D' Ayala \& Hui W. (2006), 'Conservation practice of Chinese timber structures', Journal of Architectural Conservation July, pp. 6 -26.

${ }^{42}$ Ibid, p. 11
} 
the provision of the Venice Charter and endorsed the Burra Charter as similar to the Chinese Principles. In 2003, the Indonesian Heritage Conservation Network and ICOMOS-Indonesia issued the Indonesia Charter for Heritage that stresses the heritage of Indonesia as the legacy of nature, culture, and saujana, a weaved of the two; and that heritage comprises tangible and intangible heritage. In November 2004, members of the Indian National Trust for Art and Cultural Heritage (INTACH) gathered in New Delhi, and adopted the Charter for Conservation of Unprotected Architectural Heritage and Sites in India. This Charter adopts the Nara Document that emphasizes the living heritage in the judgments of authenticity such as "the living heritage of master builders, namely Sthapatis, Sompuras, Raj Mistris who continue to build and care for buildings following traditions of their ancestors" (Article 3).

The changing notion of authenticity is indicated in the Charters in Asia that reaffirmed the Nara Document with strongly emphasizing the cultural diversity and the intangible heritage. This trend has further developed in the 1998 UNESCO's Proclamation of Masterpieces of the Oral and Intangible Heritage of Humanity and the 2001 UNESCO Universal Declaration on Cultural Diversity, and reached its climax in the adoption of the 2003 UNESCO Convention for the Safeguarding of the Intangible Cultural Heritage. ${ }^{43}$ The rise of interest on the intangible heritage has fostered the emergence of a different value system that challenged the Western concept of conservation, and stimulated the search for the Asian conservation practice.

\section{CONTEMPORARY CONSERVATION PRACTICE IN ASIA}

In line with the emergence of contemporary conservation theory in Asia, conservation practice in Asia has also shifted from the object to the inclusive approach and the emphasis on intangible heritage in conservation.

\section{The Experts Challenging the State}

The third wave of conservation in Asia is widely and vast that emerged from the democratization of heritage, such as a growing number of experts who involve in community campaigns to protect old buildings as in many newly found NGOs, an increase number of conferences and workshops on conservation of heritage, a sizable increase in the number of publication on heritage such as books written by academic, and an increase websites setup by many students and young people. The focus of conservation has also started to shift from 'monumental quality' to the inclusive approach. This growing public support in influencing policy-making on heritage issues in which the official policies have stressed the importance of the local culture and cultural heritage. For examples in Hanoi, the new middle class challenged both the state and private developers such as the case of Golden Hanoi Hotel development that was successfully stopped as a result of public protest in 1996. The protest is done as this new building would have had a major visual impact on the Ancient Sino-Vietnamese and French colonial quarters. ${ }^{44}$ In Hong Kong an increase in public monitoring initiatives, such as the protest in 2000 to conserve the Tai $O$ fishing village as the last remaining

43 In Article 2 of the Convention, intangible cultural heritage means '. . . the practices, representations, expressions, knowledge, skills - as well as the instruments, objects, artefacts and cultural spaces associated therewith - that communities, groups and, in some cases, individuals recognize as part of their cultural heritage. This intangible cultural heritage, transmitted from generation to generation, is constantly recreated by communities and groups in response to their environment, their interaction with nature and their history, and provides them with a sense of identity and continuity, thus promoting respect for cultural diversity and human creativity'.

${ }^{44}$ W.S. Logan (2002), 'The Golden Hanoi and heritage protection in Vietnam's capital: containing cultural globalization' in The Disappearing 'Asian' City: Protecting Asia's Urban Heritage In Globalizing World, ed. W.S. Logan, Oxford University Press, New York. 
'stilt house' community that is not designated as heritage by the government. ${ }^{45}$ In Indonesia, challenging the states is mostly led by the academics and professionals to promote community awareness and participation, through many local institutions. ${ }^{46}$

\section{The Inclusive Approach}

These challenges have shifted the attitude and approach of authority on inclusive conservation in Asia. For example, in George Town, urban policies implemented by the federal government, the Penang state and the municipal council have resulted community responses to conserve the town historic districts including the social fabric or the living culture by avoiding gentrification and excessive tourism developments. ${ }^{47}$ In Bangkok an increasing number of civic associations emerged since the early 1990s has considered the inclusive approach to include the Banglamphu a Muslim community identified with gold crafts and a Mon community of the court musicians families. ${ }^{48}$ In China, in 1990s after a period of various large scale urban renewals including demolition, redevelopment and conservation of state-led activity, in 1998 small-scale house-based historic district conservation began to involve multiple actors in neighbourhood conservation. For example, in the old city of Cheng Nan, the Zhongshan Road Conservation project an effective collaboration among different interested parties was demonstrated. During the conservation work period, local government, the public, the private sector, planner, and a developer all cooperated closely and set up an implementation plan to ensure the success of the project; the cost of conservation was shared by the local government and the homeowners. ${ }^{49}$

\section{The Intangible Heritage}

In many parts of Asia, conservation of heritage is about the people by securing the continuity use of tangible heritage, and using local materials and intangible heritage such as crafts skills, knowledge and practice which were employed historically to conserve: repair, refurbish, replace, restore, and to reconstruct. For example in Guangdong province, China, the Guangyu Ancestral Hall (960-1279), traditional craftsmanship, materials and construction methods were used such as blue bricks from the same historical period salvaged from nearby sites, used the original type of mortar to restore the walls and the original red sandstone soil to restore the floor, and experiments were performed getting the right colour and ratio of red sandstone soil and lime. In the Hung Shing Old Temple, Hong Kong, the advice of a Chinese geomancy master was sought and auspicious dates chosen before restoration, community input was encouraged, with villagers inspecting the temple and attending site meetings that reinforced community pride, revived the craftspeople and generated public appreciation. The restoration works of Hindu shrine Krishan (1830s) in Punjab, India, was carried out by local residents and materials to ensure the community would be able to access the materials in the future. A work yard was established using traditional materials and machinery, river sand, lime kilns, a slaking pit and a lime mortar machine to make slaked lime. In Jakarta,

45 See J.W. Cody (2002), 'Heritage as hologram: Hong Kong after a change in sovereignty, 1997-2001' in ed. W.S. Logan, ibid, pp. 185-207.

46 The NGOs such as the first of such heritage organization- Bandung Heritage Society (1987), Bali Heritage Trust (2000), Yogyakarta Heritage Society (1991), Sumatera Heritage (1998), West Sumatra Heritage (1999), Surabaya Heritage (2007), Ternate Heritage Society (2008) and at the national level the Indonesian Heritage Trust (2004).

47 K.S. Nasution \& G. Jenkins (2002), 'George Town, pulau Pinang, Malaysia: development strategies and community realities' in ed. W.S. Logan, ibid, 208-228.

48 M. Askew (2002), 'The challenge of co-existence: the meaning of urban heritage in contemporary Bangkok' in ed. W.S. Logan, ibid, pp. 229-244.

${ }^{49}$ Zhu, Q., op.cit., pp. 59-76. 
Indonesia, the restoration of the National Archives Building (1760) was done employing local material, craftsmen, and traditional techniques that combined with modern ones. A special paint and varnish specialist based in Bali retouched the original doorframe and decorative vent light. In Penang, Malaysia, belief, knowledge and practices such as fengshui, traditional materials and skilled artisans were applied in conservation work of the Cheong Fatt Tze Mansion. The analysis showed that water of the rain gutter drainage system, an element of harmony in fengshui principles, ran through floors and ceilings to cool the structure and facilitate harmonious social relations for its residents; and historic finish made from tree sap was used to coat the beams provided termite protection for the exposed structure, and the roof tiles were set in a bed of lime mortar with animal hair binder. In Pakistan, of the leaning and structurally unsound of the four 300 years old wooden mosques, Yarikutz, Rupikutz, Kuyokutz and Mamorukutz were realigned by removing the heavy earth-covered roofs, replaced using new soil, and compacted by foot in the traditional manner. All timber surfaces were treated using the traditional wood preservation technique applying walnut rind followed by linseed oil. ${ }^{50}$

\section{THE ASIAN TRADITION OF CONSERVATION}

The Western perspective that associated only with tangible qualities is rooted from the Western culture as the origin of Western materialistic approach to historical monuments lies in the Christian tradition, the tradition of the cult of holy relics as one of the bases for the doctrine of the Roman Church. ${ }^{51}$ The notion of intangible heritage that adopted in the previous Asian conservation charters and practice are rooted from the Asian tradition of conservation as discussed in the following.

\section{The Spiritual Meanings}

In Western architecture the perfection of form is achieved through realistic expression or a visual form while in East Asia the material form is a mean for transmitting the spirit values, for example the Kyeongbok Palace complex in Korea erected in 1395 was reconstructed in 1867 and extended with new buildings, however the reconstruction did not change the spirit of the place - the spatial structure of the Palace that represents the I Ching philosophy, astronomical thought, and yin-yang principles. ${ }^{52}$ In China, architecture has been shaped by cultural factor such as cosmological system, the concept of unity of heaven and human, the concept of Feng Shui; and historical factors such as activities and events, and evolution and change. ${ }^{53}$ In this historical evolution and change architecture has been shaped by preserved, damaged, destroyed, abandoned, reconstructed, and even rebuilt elsewhere. Similarly in Southeast Asia, architecture is also formed by symbolic considerations as representation of social system such as duality of male/female, married/unmarried, sacred/profane; and cosmological system such as concept of three-tiered cosmos, rules of orientation, four cardinal points, the house as body (anthropomorphic system), source of power, and ritual of construction, and these characteristic of architecture were seemed so strange to Europeans when they first encountered it due to the different perception. ${ }^{54}$

\footnotetext{
${ }^{50}$ For more examples see R. Engelhardt \& M.H. Unakul (eds.) 2007, Asia Conserved: Lesson Learned From The UNESCO Asia-Pacific Heritage Awards For Cultural Heritage Conservation (2000-2004), UNESCO, Bangkok.

${ }^{51}$ A. Tomaszewski 2005, 'Tangible and intangible values of cultural property in Western tradition and science', Proceedings of ICOMOS 15th the Scientific Symposium, Xi'an.

52 S.J. Chung 2005, 'East Asian value in historic conservation', Journal of Architectural Conservation vol. 11, no. 1 , pp. 55-70.

53 S. Xu 2005, 'On the concept of setting: a view based on China's theory and practice of cultural heritage conservation', Proceedings of ICOMOS 15th the Scientific Symposium, Xi'an.

${ }^{54}$ R. Waterson 1990, The Living House, Oxford University Press, Singapore; and J. Widodo, op.cit., pp. 1-18.
} 


\section{The Notion of Non-Permanence}

In Asia, wooden structure is a common feature in which the method of dismantling and assembling is periodically used that introduce new elements and gradually loss its original materials. ${ }^{55}$ In China, for about 3,000 years the use of timber in buildings has evolved without major change based on the principle of prefabrication and dry assembly of all structural components that makes dismantling and resembling of the whole building relatively uncomplicated. Since timber is vulnerable to climate as water leakage and infiltration are the most common cause of decay and lost of its structural capacity, therefore, historically total replacement or component renewal was a standard remedy to component deterioration. Traditional interventions for buildings may allow minor repair such as annual or seasonal repair; refurbishment such as renewal of building surface without structural touch; major restoration such as disassemble and assemble roof, timber components, and even opening up foundation; and reconstruction including extension to accommodate new needs. ${ }^{56}$

In a particular case in Japan, the Ise Shrine has been demolished and reconstructed sixty times in identical form for every twenty years since the seventh century to show the original design intent and craftsmanship. ${ }^{57}$ In India, the concept of jeernodharanam or regeneration of what decays is the traditional ways of building and maintaining architectural heritage and still exists today (INTACH). In the fifteenth to seventeenth century, perishable building structures was also the appearance in Southeast Asia cities which were extremely larger by European standards of the time, whereas the style and layout of these urban was very unfamiliar to Europeans as a 'rural' appearance with pilestructure wooden houses concealed within their spacious yards of coconut and banana trees. This wooden elevated houses was adaptable to climate whereas the Chinese and European built brick buildings were unventilated, unhealthy, and exposed to both sun and flood; and in the case of war the king and his people could escape easily with their most valuable and movable properties such as the fruits, herbs, instead of houses as burned houses will be easily rebuilt again. ${ }^{58}$

In short, cultural heritage in Asia is shaped by philosophical, cosmological and religious systems that emphasis the intangible rather than the tangible. This leads to several key differences in Asian conservation as replacement or renewal of fabric, and reconstruction are acceptable although has lost its material authenticity, because of the perishable structure and the significance of the place resides primarily in its continued spiritual meaning and symbolic value rather than importance of the fabric itself. ${ }^{59}$ This practice is less likely to be chosen in Western practitioners as original material is embedded with historic information such as age, form of cutting, and clues to changes. ${ }^{60}$

\footnotetext{
55 M. Sekino 1972, 'The preservation and restoration of wooden monuments in Japan' in Preserving And Restoring Monuments And Historic Buildings, UNESCO, Paris.

56 D. D'Ayala \& Hui W., op.cit., pp. $6-26$.

${ }^{57}$ Waterson, ibid., p. 15.

${ }^{58}$ A. Reid, op.cit., p. 77-90.

${ }^{59}$ C. Wei \& A. Aass (1989), 'Heritage conservation East and West', ICOMOS Information vol. 3; L. Pressouyre 1993, The World Heritage Convention Twenty Years Later, UNESCO Publishing, Paris.

${ }^{60}$ A. Orbasli 2008, Architectural Conservation, Blackwell Publishing, Oxford, p. 149.
} 


\section{CONCLUSION}

Conservation history has to be viewed not in one linear line starting from the West but in parallel sequences of both from the East and West as they have different traditions that affected the course of conservation. In the West, the framework of the nineteenth century classical conservation theory has been reflected in the Western-originated conservation thoery such the Athens Charter, the Venice Charter, and the other documents of UNESCO-ICOMOS. Such documents have their origins in European culture, and they were imposed by the 'authorized' institution such as UNESO and ICOMOS to the member states and the national ICOMOS in the Asian countries acting as privileged interpreters of the past. This imposing in Asia has been structured in many conservation ordinance and principles as the inheritance of the colonial power, and constructed by the post colonial state during the waves of conservation in the 1970s and 1990s. As a result of this state-led conservation in Asian urban ports and capitals, the people were excluded as the main "focus" is the object, while much cultural heritage being carried out in the name of heritage conservation to serve the people, but actually serving the interests of capital for real estate industry, tourism industry, and as a particular instrument of state policy or ideology. In the end of the twentieth century, the shift from the object to the subject in contemporary conservation theory that acknowledged the plurality of meanings, functions and values for the same object of conservation for different people has also reflected in many Charters in Asia. Unfortunately, the classical conservation point of view is still held both in conservation theory and practice in many Asian countries, especially for the perishable architectural heritage.

In a parallel course of history, conservation tradition in Asia has to be traced back to many centuries. In Asia, many cultures have a spiritual rather than material view in which objects and places as vehicles of great value for communicating deeper, spiritual meanings. The important of spiritual meanings in fabric reflects in the conventional conservation practices in Asia as the people were always the centre in conservation, buildings were built, repaired, restored, rebuilt or reconstructed, and extended by the people with their craftsmanship, rituals, and spiritual knowledge for their continuing need of everyday life. In short, to conserve or actions to prolong the life of buildings, the Asian tradition of conservation leads to the common practices of the notion of transformation: renewal as opposed to the notion of material authenticity that keeps the notion of minimal intervention and reversibility in conservation. ${ }^{61}$ Hence, conservation theory should be rewritten that rooted in the Asian tradition for future conservation practice in Asia region, especially for the majority of perishable architectural heritage. ${ }^{62}$

\footnotetext{
${ }^{61}$ In contemporary theory, the principle of minimum intervention is a reminder that conservation is done for specific reasons and should keep the destruction of evidence to a minimum (M. Vinas, 2005: p. 192).

62 For example, in Japan 90 percent of the listed national heritage (3,646 buildings) is wooden structure (Supardi, 2003: p. 34).
} 


\section{REFERENCE}

Askew, M. (2002), 'The challenge of co-existence: the meaning of urban heritage in contemporary Bangkok' in The Disappearing 'Asian' City: Protecting Asia's Urban Heritage In Globalizing World, ed. W.S. Logan, Oxford University Press, New York.

Avrami, R., Mason, R. \& De La Torre, M. eds. 2000, Values and Heritage Conservation, Getty Conservation Institute, Los Angeles.

Balderstone, S., Qian, F. \& Zhang, B. 2002, 'Shanghai reincarnated' in The Disappearing 'Asian'City: Protecting Asia's Urban Heritage In Globalizing World, ed. W.S. Logan, Oxford University Press, New York.

Cleere, H. 2001, 'The uneasy bedfellows: universality and cultural heritage' in Destruction And Conservation Of Cultural Property, eds. Layton, R., Stone, P.G. \& Thomas, J., Routledge, London.

Cleary, M.C. 1997, 'Colonial and post-colonial urbanism in north-west Borneo, in Contested Urban Heritage: Voices From The Periphery, B. Shaw \& R. Jones, Ashgate, Singapore.

Chung, S.J. 2005, 'East Asian value in historic conservation', Journal of Architectural Conservation vol. 11 , no. 1 , pp. 55-70.

Cobban, J.L. 1985, 'The ephemeral historic district in Jakarta', Geographical Review, vol.75, no.3, pp. 300-318.

Cody, J.W. 2002, 'Heritage as hologram: Hong Kong after a change in sovereignty, 1997-2001' in The Disappearing 'Asian' City: Protecting Asia's Urban Heritage In Globalizing World, ed. W.S. Logan, Oxford University Press, New York..

Chu, C. 2007, 'Heritage of disappearance? Shekkipmei and collective memory(s) in posthandover Hongkong', Traditional Dwellings and Settlements Review, vol. XIII, no. 2, pp. 4355 .

D' Ayala, D. \& Hui, W. 2006, 'Conservation practice of Chinese timber structures', Journal of Architectural Conservation July, pp. 6-26.

Deslagen, W. 1994, Architectural Restoration in Western Europe: Controversy And Continuity, Architectura \& Natura Press, Amsterdam.

Engelhardt, R. \& Unakul, M.H. (eds.) 2007, Asia Conserved: Lesson Learned From The UNESCO Asia-Pacific Heritage Awards For Cultural Heritage Conservation (20002004), UNESCO, Bangkok.

Emerick, K. 2001, 'Use, vale and significance in heritage management' in Destruction And Conservation Of Cultural Property, eds. R. Layton, R., Stone, P.G. \& Thomas, J., Routledge, London.

Funari, P.P.A. 2001, 'Destruction and conservation of cultural property in Brazil: academic and practical challenges' in Destruction And Conservation Of Cultural Property, eds. Layton, R., Stone, P.G. \& Thomas, J., Routledge, London. 
Fu, C.C. 2005, 'Cultural sensitivity towards intangible values in monuments and sites-a comparison between Eastern Asian and Western countries', ICOMOS 15th the Scientific Symposium, Xi'an.

Jones, R. \& Shaw, B.J. 2006, 'Palimpsets of progress: Erasing the past and rewriting the future in developing societies-case studies of Singapore and Jakarta', International Journal of Heritage Studies vol. 12, no. 2, pp. 122-138.

Henderson, J. (2000) 'Attracting tourists to Singapore's Chinatown: a case study in conservation and promotion', Tourism Management vol. 21, pp. 525-534.

Logan, W.S. (2002), 'The Golden Hanoi and heritage protection in Vietnam's capital: containing cultural globalization' in The Disappearing 'Asian' City: Protecting Asia's Urban Heritage In Globalizing World, ed. W.S. Logan, Oxford University Press, New York.

Loulanski, T. 2006, 'Revising the concept for cultural heritage: the argument for a functional approach, International Journal of Cultural Property vol. 13, pp. 207233.

Maclaren, F.T. \& A. Villalon, 2002, 'Manila's Intramuros: storming the walls' in The Disappearing 'Asian' City: Protecting Asia's Urban Heritage In Globalizing World, ed. W.S. Logan, Oxford University Press, New York.

M. Vinas, S. 2005, Contemporary Theory of Conservation, Elsevier-Butter WorthHeinemann, Amsterdam.

Nasution, K.S. \& Jenkins, G. 2002, 'George Town, pulau Pinang, Malaysia: development strategies and community realities' in The Disappearing 'Asian' City: Protecting Asia's Urban Heritage In Globalizing World, ed. W.S. Logan, Oxford University Press, New York.

Orbasli, A. 2008, Architectural Conservation, Blackwell Publishing, Oxford, UK.

Powell, R. 1997, 'Erasing memory, inventing tradition, rewriting history: planning as a tool of ideology' in Contested Urban Heritage: Voices From The Periphery, B. Shaw \& R. Jones, Ashgate, Singapore.

Pressouyre, L. 1993, The World Heritage Convention Twenty Years Later, UNESCO Publishing, Paris.

Prudon, T. H.M. 2008, Preservation of Modern Architecture, John Wiley \& Sons, Hoboken.

Reid, A. 1993, Southeast Asia in the Age of Commerce 1450-1680, vols 2. Yale University Press, New Haven.

Sekino, M. 1972, 'The preservation and restoration of wooden monuments in Japan' in Preserving And Restoring Monuments And Historic Buildings, UNESCO, Paris.

Shaw, B.J. \& Jones, R. eds. 1997, Contested Urban Heritage: Voices From The Periphery, Ashgate, Singapore.

Supardi, N. 2003, Pedoman Rehabilitasi Bangunan Bersejarah, Jakarta. 
Taylor, K. \& Altenburg K, 2004, 'Cultural heritage management: possible role for Charters and Principles in Asia', International Journal of Heritage Studies, vol. 10 , no. 5 , pp. $417-33$

Tomaszewski, A. 2005, 'Tangible and intangible values of cultural property in Western tradition and science', Proceedings of ICOMOS 15th the Scientific Symposium, Xi'an.

Waterson, R. 1990, The Living House, Oxford University Press, Singapore.

Waterton, E., Smith, L. \& Campbell, G. 2006, 'The utility of Discourse Analysis to heritage studies: the Burra Charter and social inclusion', International Journal of Heritage Studies, vol. 12, no. 4, pp. 339-355.

Wei, C. \& Aass, A. (1989), 'Heritage conservation East and West', ICOMOS Information vol. 3.

Widodo, J. 2004, The Boat and the City: Chinese Diaspora and the Architecture of Southeast, Marshall Cavendish Academic, Singapore.

$\mathrm{Xu}, \mathrm{S} .2005$, 'On the concept of setting: a view based on China's theory and practice of cultural heritage conservation', Proceedings of ICOMOS 15th the Scientific Symposium, Xi'an.

Zhu, Q. 2007, 'Historic district conservation in China: assessment and prospects', TDSR vol. XIX, no. 1 , pp. 59-76. 